I Graduate Institute of International and Development Studies (IHEID), Geneva, Switzerland; Federal University of Rio de Janeiro (UFRJ), Rio de Janeiro, RJ, Brazil grazi.moraes.silva@gmail.com

I I University of California Santa Barbara (UCSB), Department of Anthropology, Santa Barbara, CA, United States of America

saldivar@anth.ucsb.edu

\title{
COMPARING IDEOLOGIES OF RACIAL MIXING IN LATIN AMERICA: BRAZIL AND MEXICO
}

\section{INTRODUCTION}

Academic interpretations of racial mixing in Latin America, particularly in the North American literature, underwent a radical change during the second half

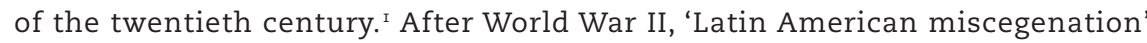
was seen as an alternative to ethnic and racial exclusions that had triggered the Jewish holocaust and had been a source of violent conflicts in the United States during the Jim Crow era and in South African apartheid during the I950s and I960s. But by the end of the twentieth century, with the rise of multicultural discourses and identity politics, Latin American ideologies of racial mixture became increasingly denounced as myths that conceal (and thus support) the reproduction of racial inequalities (e.g. De la Cadena, 2000; Hanchard, I 994).

These studies have largely been guided by comparisons between countries with widespread racial mixing (usually Brazil, Mexico or Colombia) and countries in which it was less encouraged and visible (most commonly, the USA). Such comparisons have largely contributed to a better understanding of miscegenation as an ideology that allowed racial inequalities to remain more invisible in the Latin American context throughout most of the twentieth century (e.g. Telles, 2003 and Knight, I990). More recently, a number of authors have also stressed the influence of Latin American ideas of miscegenation in the transformation of racial inequalities in the United States, a phenomenon that has been labeled the Latin Americanization of American race relations (e.g. 
Bonilla-Silva, 2004). Exploring this comparison, these studies have usually treated racial mixture as a coherent ideology shared across the region.

In this paper we propose to shift the focus onto the diverse ways in which racial mixture currently impacts racial formations in the region. Empirically, we turn our gaze to Brazil and Mexico, two of the largest countries in Latin America, and also those with the largest Afro-descendant and indigenous populations in the continent. As in most countries in the region, ideologies of racial mixture were instrumental to the construction of their national identity: first as a strategy for whitening (Stepan, I99I) and later as tools for assimilation (e.g. Freyre, I946, and Gamio, 2010). Today, ideas of racial mixing remain central in both Brazil and Mexico, but racial politics are significantly different. Brazil has increasingly seen black (pretos) and brown (pardos) people join forces to address racial inequalities, arguing that mixed pardos are in similar conditions to blacks. Mexico, by contrast, still advocates the benefits of racial mixture, avoiding the discussion of race and racial inequalities on the grounds that most of the population is mixed.

Our paper unfolds as follows: first we explore the role of racial mixing in the nation building processes in Brazil and Mexico. We emphasize the similarities in the ways in which this idea has been articulated in the two countries historically, but also the important differences, something often overlooked in the literature. Next, turning to PERLA data (presented in our methods section), we discuss how these differences have created distinct perceptions of racial identification in Brazil and Mexico, focusing on three dimensions: (I) the relationship between racial identification and skin color, (2) the relationship between racial mixture and cultural differences, and (3) the impact of racial mixture on ethnoracial inequalities. ${ }^{2}$ We conclude by stressing the need for more comparative studies between Latin American countries in order to better understand the diversity of mestizaje projects and their differential impacts in the region.

\section{RACIAL MIXTURE IN BRAZIL AND MEXICO: SIMILARITIES AND DIFFERENCES}

Two of the largest countries in Latin America, Brazil and Mexico also have the region's largest populations of black and indigenous peoples, respectively. In addition, they have commonly been cited as two of the most striking examples of the success of racial mixing ideas as tools for nation-building (Telles \& Garcia, 2013).

From the early twentieth century onwards, Latin American intellectuals moved away from ideas based around scientific racism that defended the importance of racial purity. Instead racial mixing was advocated as a route to create a new 'race' or 'national character' which would combine the best features of each group. Two leading proponents of these ideas were José Vasconcelos and his defense of Mexicans as a cosmic race, and Gilberto Freyre's myth of the three races as the basis of Brazilian exceptionalism. Such images proved highly in- 
strumental in the creation of both nation states where the diversity of the population and the lack of a single ethnic core were deemed problematic (Appelbaum, Macpherson \& Rosemblatt, 2003). It was during the first decades of the twentieth century that popular and syncretic signs went from being stigmatized - and even criminalized - practices to national symbols (Skidmore, I976).

These ideas seem particularly important in a period of social unrest caused by growing urbanization and increasing social stratification (Marx, I998; Knight, I990). Intentionally or not, notions of racial mixture provided a way to forge ideas of equality while maintaining an economy based on dramatic inequality (Saldivar, 20I4).

But while these ideas of symbolic inclusion may have created a universal sense of national citizenship based largely on mixture, the overlapping of national identification and racial mixture also implied a national identity based on sameness, which particularized (and consequently excluded) certain groups who affirmed their difference or who were categorized as different. This concept of unity based on racial and cultural mixture exhibited a number of "paradoxes of hybrid homogeneity," to use Alexandra Stern's apt phrase (Stern, 2009: I58). Illustrations of such intolerance include the prohibition of schooling in German in the South of Brazil (Seyferth, I997) or Chinese political persecution and hate crimes in Northern Mexico, which often led to the expulsion of mixed families (Renique, 2003).

Nevertheless, in the mid-twentieth century, in contrast to the United States Jim Crow laws, Brazilian racial democracy and Mexican mestizaje were commonly presented as inclusive and egalitarian ideologies (Harris, I964; Van Den Bergue, I967). Both internally and externally, Brazil and Mexico were seen as examples of non-racist societies. In the Brazilian case, UNESCO funded a series of studies to understand the 'success' of race relations in the country (Maio, I999). Even though the results were not as optimistic as predicted, they worked to confirm the international image of Brazil. Similarly, Mexico's mestizaje inspired scholars like sociologist Robert Park to consider that the 'mix-blood' (the intermediary man) would be the mediator between races and cultures, since he had a broader perspective making him "the most civilized of humankind" (Cunin, 2002: 25).

Today, scholars largely acknowledge the existence of racial inequalities and discrimination against indigenous and black populations in Mexico and Brazil, respectively. Nevertheless, the acknowledgment of inequalities co-exists with the celebration of racial mixture as a key element of national identities (Telles \& PERLA, 20I4). Although these similarities between Brazil and Mexico justify including both countries under the rubric of racially mixed countries, there are also important differences that become understated under this shared label. Here we focus on three of these differences: the historical position of black and indigenous people in both countries, the centrality of ideas of racial 
mixture in the Brazilian and Mexican political transformations in the early/mid twentieth century, and the statistical visibility of ethnoracial groups in these two contexts.

A first difference is the presence of indigenous and African populations in the two countries. Brazil was the largest importer of slaves in the region and nearly decimated its indigenous population across most of its territory (with the exception of Amazonia). Brazilian racial mixture, therefore, is mostly understood as an issue of blacks and whites, though indigenous people do play an important symbolic role. By contrast, the indigenous presence was much stronger in Mexico. Although the number of black people (and African slaves) was larger than Spaniards until the eighteenth century, their presence has been deliberately erased from the Mexican imaginary (Moreno Figueroa \& Saldivar, 20I5; Sue, 20I3; Velazquez, 20I I).

But this difference is not simply demographic. As argued by Wade (I997) and Hooker (2005), black and indigenous populations have been historically perceived (and treated) as distinctive in Latin America. The history of black people in Latin America has commonly been studied through the history of colonization and slavery and, currently, of racism and discrimination. In contrast, the history of indigenous people has often been treated as one of separate ethnicities, or separate cultures, outside of (or parallel to) the national history.

These differences are partially explained by the distinct positions that black and indigenous populations had at the time of Latin American colonization. Blacks, or black Africans, had a longer history of contact with Europeans and by the time of the colonization of the Americas were perceived as 'natural' slaves by religious theories that described them as the soulless children of Cain (Banton, I998). Native indigenous populations, however, were a puzzle to colonizers and their status as humans was the subject of well-known theological debates. Furthermore, the black presence was not homogenous throughout the region. In countries like Mexico, Argentina and Peru, African slavery was concentrated in certain regions and the black presence perceived as residual and secondary to national narratives. Brazil and Caribbean countries like Cuba and the Dominican Republic are commonly presented as regional exceptions due to the centrality of the African presence, both demographically and culturally.

In short, as aptly summarized by Wade, while black people were perceived as a race, who suffered discrimination due to their phenotype, indigenous people were perceived as cultural others, who were stigmatized (and sometimes glamorized) due to their culture. Black and indigenous populations, therefore, have often been treated as separate topics.

Building on this distinction, Hooker (2005) considers that the focus of Latin American multicultural policies on ethnic distinctions has failed to address racial discrimination. She claims that this is most clearly seen in the case of Afro-Latinos due to the fact that they are not normally recognized as a dif- 
ferent 'autochthonous' culture. Collective rights based on group difference became the main target of reparation policies: consequently, groups that are not perceived as culturally distinct or that are simply invisible, the case of black populations in most of Latin America, have not benefited from so-called multicultural policies. More broadly, the author claims that these policies cannot address "structurally persistent inequalities faced by primarily racially-defined groups" (Hooker, 2005: 308-9).

Indeed the different forms of racialization of indigenous and African populations are central to Latin America's racial projects. Yet, as Wade (I997) has stressed, by reducing indigenous identity to culture and blackness to phenotype, they have ignored the similar subordinate position that indigenous and black people have occupied in relation to whites in Latin American nationbuilding. In this sense, both identities have been racialized. We agree with Wade that while recognizing the differences between black and indigenous histories in Latin America, it is important to bring them into the same theoretical frame of reference in order to explore similarities and differences in national racial projects in the region, like those of mestizaje. By defining racial identification - whether indigenous or black - as social construct, we can better understand how they contributed to a third socially constructed racial identity in the region, that of the mestizo.

A second key difference is the centrality of the discourse of mestizaje within the broader political transformations in Brazil and Mexico in the early twentieth century. The so-called I930 Brazilian Revolution and the I9Io-I9I7 Mexican Revolution are commonly understood as turning points in racial discourses. Nevertheless, while the Mexican Revolution deliberately relied on mestizaje as a key element of the new nation, in Brazil the link between Vargas and racial democracy is less straightforward. This is partly due to what has been described as a Brazilian history of continuities, which never experienced a political rupture similar to the Mexican revolution.

Vargas's bloodless revolution in the I930s, followed by a dictatorship from I937-I945, is usually presented as a rupture with a formally liberal (and corrupt) republic to a populist (and authoritarian) regime. Understanding the consequences of Vargas's economic and social policies for Brazil's black and brown population is not simple. From the south of Brazil, Vargas was intellectually influenced by positivist philosophy. At least until the beginning of I940s, he supported European authoritarian ideologies, such as Mussolini's fascism. In this ideological vein, he maintained immigration restrictions against blacks and Asians and implemented new ones to guarantee and develop "the ethnic composition of the population and the most convenient characteristics of European descent" (Skidmore, I976).

At the same time, as part of his authoritarian project for modernizing the country, Vargas strengthened the national labor force's participation in the 
modern industries. The I937 authoritarian constitution set quotas on hiring foreign employees (insisting that they should comprise no more than one third of any Brazilian firm), indirectly benefitting urban Afro-Brazilians. Many black and brown workers migrated from rural areas and the Northeast and started employment in the manufacturing industries or in the public sector. These changes, however, were not accompanied by the language of race or mestizaje, and many authors have stressed continuity, rather than rupture, with the whitening ideas of the earlier decades.

Nevertheless, Vargas's nation-building strategy did contribute to the acceptance of Afro-descendant cultural expression, considered an essential element of the national identity ever since. The I938 official celebrations of the $50-$ year anniversary of the abolition of slavery presented the negro as a national monument (Cunha, I999). The I940 National Penal Code suspended previous restrictions on popular cultural expressions, such as samba, capoeira, and others related to African traditions. Accepting black (and indigenous) cultural expressions as fundamentally Brazilian was part of a new understanding of racial mixture as the basis of national identification, rather than as a problem to be solved. ${ }^{3}$

Intellectually, this transformation was personified by Gilberto Freyre, an anthropologist trained at Columbia University, and his I933 masterpiece Casagrande \& senzala (Masters and Slaves). The connection between a mestizaje intellectual project and the Brazilian 'New State,' however, seem to be much more tenuous than the one in Mexico, where mestizaje was openly presented as the regime's official ideology. Freyre was an explicit critic of the Vargas regime from I937 onwards. Moreover, the acceptance of negros at a cultural level occurred simultaneously to their stigmatization under federal laws against vadiagem (vagrancy) and criminology theories that portrayed negros as a dangerous race (Cunha, I999). In short, even though ideas of racial mixture are widespread in Brazil, their connection to deliberate State policies and widespread hegemony seem more tenuous than in Mexico.

After the Mexican Revolution (I9IO-I9I7), a more popular and wider definition of mestizaje emerged as scholars and state officials like José Vasconcelos and Manuel Gamio blamed the rebellion on cultural, racial and socioeconomic differences, and imagined as a remedy the creation of a uniform citizenry forged through the process of mestizaje (Lomnitz-Adler, I996; Poole, 2004; Saldivar, 2008 and 20I4). The Mexican state designed a number of policies to modernize the country through education and development projects, which did not allow for the possibility to be indigenous and modern at the same time.

These policies included the modernization of indigenous communities through education and their incorporation into the capitalist economy as labor and consumers. Without policies like Republicas de Indios, indigenous people had few incentives to preserve their social identity. Development policies encouraged migration to the cities, further encouraging a migrant population to abandon in- 
digenous identification - perceived as essentially cultural - and become mestizos. Simultaneously, because the mestizo identity was presented as a synonym to a mexicanidad, part of the elite who earlier identified as white also increasingly selfidentified as mestizo. The convergence of previously indigenous and white Mexicans in a mestizo identity allowed race to be erased as a social issue. Moreover, by recognizing cultural differences, rather than race, as the 'real impediment' that kept indigenous people impoverished and isolated, the state developed a series of economic and educational policies aimed to assimilate and change their cultural traces (i.e. self-sufficiency, language, and so on), thus converting racial inequalities into a problem of assimilation instead of social injustice (Saldivar, 20I4).

The third difference is in part a consequence of the first two: the distinct forms of racial categorization historically carried out by the state in Brazil and Mexico during the twentieth century, particularly in the censuses. While Brazil continuously collected data on skin color and racial identification throughout the century, Mexico mostly collected data on indigenous languages.

Among all Latin American countries, Brazil is probably the one that has most systematically collected data on race, albeit using color rather than race as an identifying label. It is possible to find data in the I 872 and I 890 Censuses and in most of those from the twentieth century. ${ }^{4}$ In nearly all of them, respondents are asked about their color and classified (until I960) or asked to identify themselves (from I980 onwards) as white (branco), brown (pardo), black (preto), yellow (amarelo, since 1940 to include the Asian population), and indigenous. This last category was included in I990, and, without much debate, triggered the rephrasing of the census question to "What is your color or race?"5

Figure I compares the distribution across census racial categories between I 872 and 20I0. Taken at face value, this graph shows that: (I) the frequency of black people fell steadily until I990, when it slowly started growing again; (2) the frequency of white people followed the opposite path, growing steadily until I940, when it started to slowly decline; (3) by contrast, the frequency of people who identify as pardos, the mixed race category, increased almost steadily from I940, its lowest point. The frequency of yellow and indigenous people remained constant at around I\% or less of the population.

A more hidden feature of this graph is the transformation of the meanings of racial categories across the censuses. In the first censuses, census reports and introductions (I870-I940), the goal of racial statistics was to measure the politically desired 'whitening' of the population. The exclusion of the pardo category in the 1940 census has been defined as a (successful) strategy to increase the number of whites (Nobles, 2000). ${ }^{6}$ The I 980 census shows a transformation in the understanding of racial categorization with the adoption of self-identification (rather than interviewer classification), repeated in the following censuses. This transformation gives much more agency to social actors, who can now 'choose' their racial identification, often relying on the valorization of mixed (and often whiter) identities. 


\section{Distribution of Racial Labels across Brazilian Censuses (I872-2010)}

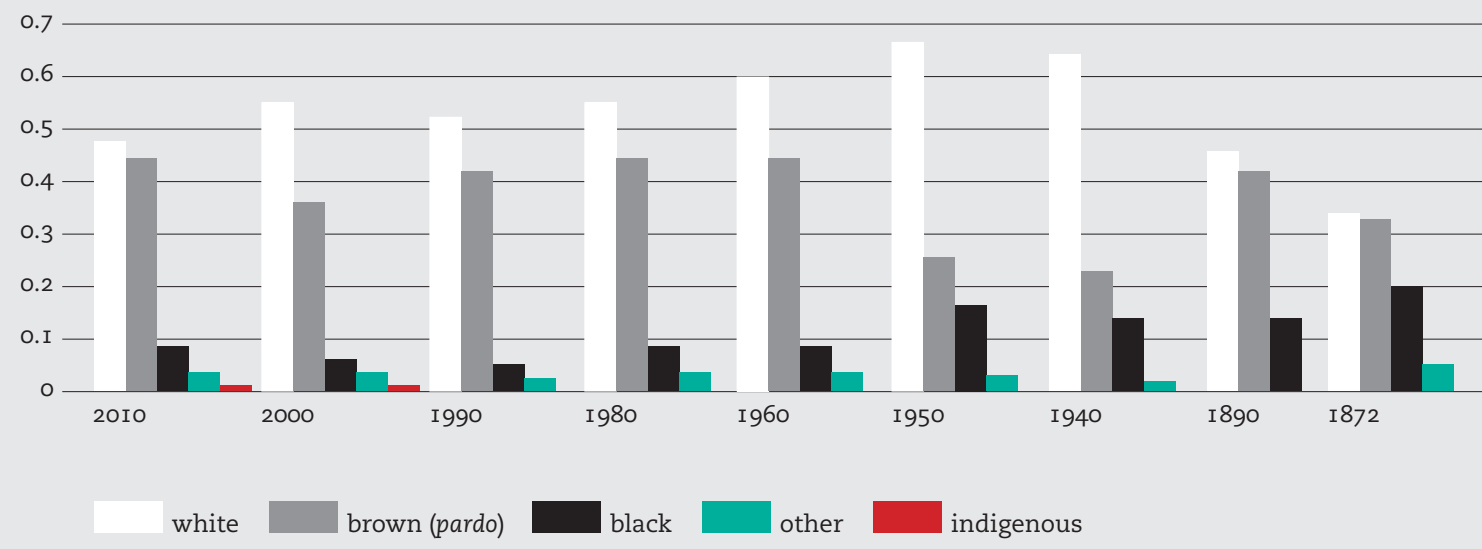

Figure I

Distribution of Racial Labels across Brazilian Censuses (I872-2010) Source: IBGE Censuses I872-2010 (frequencies available on webpage, included in graph by authors)

The exclusion of racial counting in the I970 Census is mostly interpreted as the culmination of the idea that Brazil was a mixed country. Although it is not possible to document the direct influence of the military government in the exclusion of the question (Powell \& Moraes Silva, 20I8), the period has been defined as the peak of an official discourse of racial democracy, with the presence of Gilberto Freyre in the elaboration of the military government's plan and the political persecution of black activists.

After redemocratization (in the late i980s), black movements denounce of the "myth of racial democracy" became stronger. The elimination of the brown (pardo) category was one of their demands, to encourage people to embrace their negro identities (Hanchard, I994). Identification as negro was understood to have a more political meaning in terms of denouncing the persistent racialization of Brazilian society and increase racial consciousness, but surveys show that until recently it was spontaneously chosen by less than I0\% of the population.7 Although the black movement did not succeed in changing the categories, from the I980s onwards official institutions began to increasingly join those who identified pretos (black) and pardos (brown) as negros (black) in studies and policy reports on racial inequalities (Powell \& Moraes Silva, 20I8). 
Sociological studies conducted since the ig7os had already used census data to demonstrate the persistence of racial inequalities between whites and non-whites: pretos and pardos were shown to be equally disadvantaged when compared to the white population, even after including statistical controls for class (e.g. Hasenbalg, I979 and Vale e Silva, I979). But it was in the I990s that the State recognized the existence of racial inequalities and in the early $2000 \mathrm{~s}$ that a number of racially-targeted social policies were implemented, the most well-known being racial quotas for public university places (Telles, 2003).

The implementation of racial quotas in Brazil triggered heated debates about the role of race discrimination in the country, and a number of scholars and intellectuals opposed them (Fry et al., 2007). But the statistical visibility of racial inequalities, enabled by the presence of census data on race/color through most of the twentieth century, has been a key element in arguing for the need for racially-targeted policies (Telles \& PERLA, 20I4), recently considered constitutional by the Supreme Court.

By contrast, debates on racial inequalities have been much less visible in Mexico. In the national censuses, the traditional 'ethnoracial' question has focused on language rather than ethnic or racial identification. Historically, a tension had existed between those who believe people should choose their ethnoracial identity and the scientific push to devise ways to measure the 'real' ethnoracial character of the population (Knight, I990; Saldivar \& Walsh, 20I4). This latter approach dominated, and language remained the most important marker of racial and ethnic difference in the censuses until I990, with the exception of I92I. As in the case of the black population in Brazil until the mid-twentieth century, the effort to count indigenous people was aimed at assessing integration, assimilation and nation building. As shown in Figure 2 below, between 1930 and 2000 the census showed a continuous decline in the number of people who spoke an indigenous language, interpreted (and celebrated) as a sign of the country's modernization.

As in Brazil, the nineties were a turning point in ethnoracial relations in Mexico. The legal recognition of Mexico as a pluricultural country in I992 and the subsequent implementation of multicultural policies (such as intercultural education) were followed by an important change in the 2000 census. $^{8}$ This included a self-ascription question, in which people were asked whether they belonged to any particular ethnic group. ${ }^{9}$ As shown in Figure 2, approximately $7.1 \%$ of all Mexicans spoke an indigenous language, and $6.2 \%$ considered themselves to be members of an indigenous group. $78.9 \%$ of those who identified themselves as members of an indigenous group spoke an indigenous language, and $20.9 \%$ did not. In other words, I.3\% of the total national population considered itself to be indigenous without speaking an indigenous language, and I. $2 \%$ of speakers of an indigenous language did not claim to be members of an indigenous group. 
436

\section{Ethnicity, Race and Language in Mexican Censuses, I895-2010.}

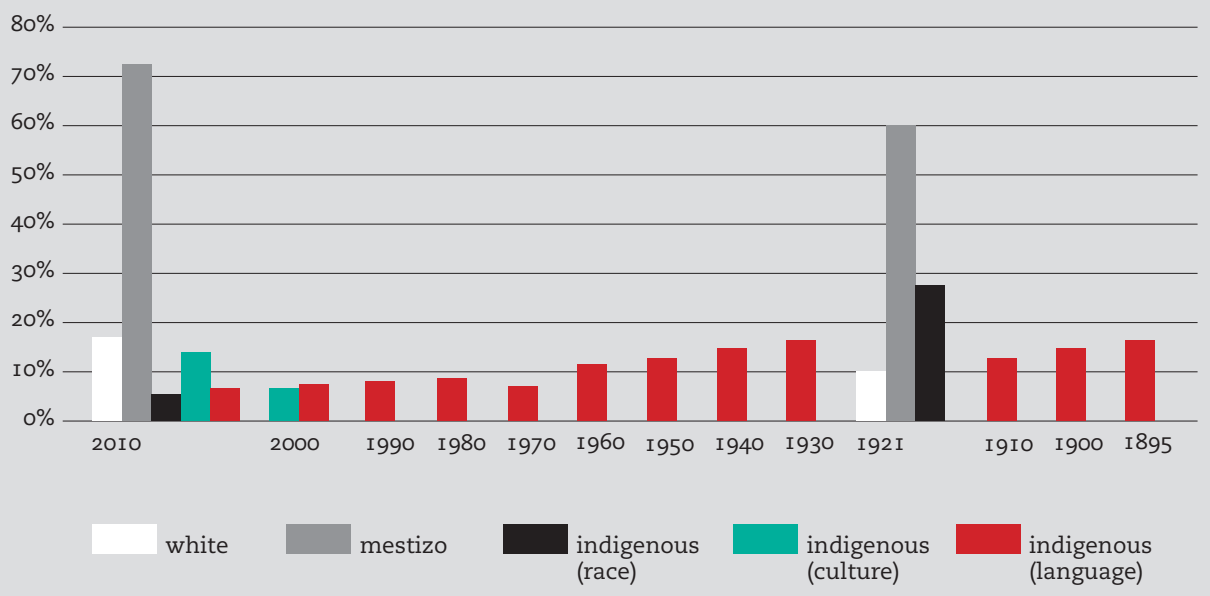

Figure 2

Ethnicity, Race and Language in Mexican Censuses, I895-2010.

Source: INEGI, I996; INEGI.gob.mx; INEGI, 2000, 20I0; and LAPOP, 2010.

In 20 Io the linguistic criteria for defining an indigenous person was further expanded to include children older than $3(6.6 \%)$ and people that understood (but did not speak) an indigenous language (I.5\%). More notably, however, the self-ascription question was reformulated in the following way: "In terms of (NAME)'s culture, does s/he consider her or himself indigenous?" "To The answers to this question show that $14.8 \%$ of Mexicans consider themselves to be part of an indigenous group because of their culture, and among these people, $56 \%$ do not speak an indigenous language (INEGI, 20I3). Figure 2 summarizes the changes in the frequencies of the ethnoracial question in Mexican censuses and in a recent national survey that collected data on racial identification, the Latin American Public Opinion Project (LAPOP).

The data on self-ascription confirms what ethnographic research had being telling us: indigenous identity does not rely solely on language (Martínez Casas, 2009; Martinez-Novo, 2006). Figure 2 also shows that self-ascription as culturally indigenous substantially increases the percentage of indigenous people in the country, showing that it is much more common for people to consider themselves carriers of indigenous culture than members of an indigenous group or speakers of an indigenous language. This should not be surprising since the recognition of an indigenous past has always being part of Mex- 
ico's national mestizo imaginary. This same imaginary may also allow people to consider themselves culturally indigenous and mestizos at the same time.

Although censuses have not asked Mexicans about their racial identification since I92I, recent surveys (LAPOP, 20IO; PERLA, 20IO, MMSI, 20I6) have shown that Mexicans identify as mestizo, indigenous, white and Afro-descendent. This indicates the persistence of categories that were supposed to have been erased under a single non-indigenous identity. LAPOP, for example, found that when asked to identify themselves racially, I7\% of the Mexican population identified as white and $5.7 \%$ as indigenous. Nevertheless, the large majority of the Mexican population, $72.84 \%$, identified racially as mestizo. This is a significant increase from the $59.3 \%$ who identified as mestizos in the I92 I Census, evidencing the partial success of the mestizaje ideology. But because we do not have data on the oscillations of this identification over the last century, it is impossible to know if mestizo identity is on the rise or in decline.

With this overview of similarities and differences in the ethnoracial formation of Brazil and Mexico we aimed to show how the broad idea of racial mixture has been historically constructed in different ways in each country. In the following sections we rely on survey data on Brazil and Mexico to analyze the impact of these historical differences in racial mixture in the current perceptions of race and in the measurement of racial inequality in these two countries.

\section{DATA AND METHODS}

In order to compare how ideas of racial mixture contribute to the contemporary racial projects in Brazil and Mexico we rely on data provided by the Project on Ethnicity and Race in Latin America - hereafter, PERLA - which surveyed a national representative sample in both countries in 20 IO $^{\text {II }}$ The sample comprised Iooo cases for each country. ${ }^{12}$

As the first comparative survey on race relations in Latin America, PERLA makes an important contribution to studies and especially comparisons within the region. While a number of national surveys on racial attitudes have been conducted in Brazil since the late I990s (e.g. DataFolha, I 995 and I998; PESB, 2003; PCERP, 2008), this type of study was the first of its kind in Mexico - further evidence of the different place that race relations occupy in these two countries. ${ }^{13}$ In short, PERLA provides the first possibility of systematic comparison of race relations between these two countries.

The survey relied on a similar questionnaire in both countries, which asked respondents about their perceptions of race relations in their country, their relationship to other ethnoracial groups and their support for a number of ethnoracially targeted policies. Interviewees were also asked general socioeconomic questions about their educational and occupational status. Finally, the survey included not only a number of questions on different ways of identifying oneself ethnoracially: an open-ended question on identity (without 
specifying any membership criteria), an open question on 'racial identity,' a closed-ended identity question based on "ancestors and customs," and a closed-ended question relying on census categories (white, mestizo/pardo, indigenous/black), but also a number of questions on the meanings of racial identification.

Relying on census racial identification, the general distribution of respondents in PERLA was $37 \%$ white, $39.7 \%$ pardo and $15.2 \%$ preto in Brazil. ${ }^{\mathrm{I}}$ In Mexico, respondents identified racially as white (I $3.2 \%$ ), mestizo (64.3\%) and indigenous (I I.9\%), following the racial categories of the I92 I Census. ${ }^{\text {I5 }}$

Given that racial identity is also based on classification by others, interviewers were used as a reference to measure how interviewees were perceived. Prior to beginning the interview, interviewers were instructed to classify interviewees according to: (I) census ethno-racial categories (black/indigenous, pardo/mestizo, white); and (2) their skin color using a color palette, or a chromatic scale, which presented a range of skin colors, varying from very light (I) to very dark (I I). The color palette is reproduced in Figure 3 (p. 440).

By using the color palette information, we are able to differentiate perceptions of skin color from perceptions of ethnoracial identification/classification. We are aware that this is a contested methodological device, but the use of the color palette is not understood here as an objective measure of skin color (or race), but as a more precise measure of skin color than race identification. The goal is to explore how much overlap there is between these different types of classification: how does skin color categorization, measured using this limited scale, help explain ethnoracial identification/categorization, ethnoracial inequality and perceptions of discrimination. The color palette was a particularly important contribution in the Brazilian case, where race and color are often understood as synonyms.

In the following sections of the paper we also rely on questions concerning the meaning attributed by interviewees to racial identification and the correlation between racial/color identification/categorization and average years of schooling, as a proxy for socioeconomic status.

\section{RACIAL MIXING AND SKIN COLOR}

As mentioned earlier, since the first Brazilian censuses, ethno-racial categories were translated into color categories. White, brown and black were said to refer simply to skin color, a marker with no relationship to culture or ancestry - illustrated by the census question: "what is your color?" This shift had two consequences: on one hand, it underplayed the importance of the distinct experiences that people from different racial backgrounds had in society. On the other, it presented Brazilian society as a color continuum in which no strong biological, symbolic or socioeconomic boundaries were possible. This, at least, was the initial understanding, later challenged by statistical studies that 
showed the persistence of inequalities between the white and non-white population, regardless of their place in the continuum (e.g. Vale e Silva, I979).

Recent studies show that the understanding of ethnoracial categories, such as skin color, in censuses resonates with the Brazilian population. When asked what it means to be black, white or pardo (brown), Brazilians commonly reply that these categories refer to skin color and phenotype. A recent survey conducted by IBGE in 2008, the Pesquisa sobre Caracteristicas Étnico-Raciais da População (PCERP), asked respondents about the criteria by which they chose their census color or race group. The study found that skin color (55\%) and phenotype (I5.4\%) are the two aspects most commonly cited as the most important in terms of racial identification (combined, cited by $70.4 \%$ ), a strong majority compared to family origin (cited by I3.I\%), socioeconomic background $(8.5 \%)$, culture $(7.2 \%)$, and politics and ideology $(0.6 \%) .{ }^{16}$

In contrast, until recently in Mexico, skin color has not been a salient category of analysis or practice. Mexico has historically focused on cultural differences between indigenous and non-indigenous people, dismissing skin color as a component. Color differences were underplayed by considering that there was only one race in Mexico, la raza de bronce (Vasconcelos, I966). Recent studies, however, have begun to consider the role of skin color in Mexican society (Moreno Figueroa, 20Io; Sue, 20I3; Villareal, 20Io; Martinez Casas et al., 20I4). Even the government agency responsible for preventing discrimination (CONAPRED) has recently experimented with a color variable in a large-scale survey to assess the prevalence of discrimination (CONAPRED, 2010).

By using the PERLA data we can more directly compare how perceptions about ethnoracial identification overlap (or not) with perceptions about skin color. Figure 3 presents the graph with the color palette categorization on the $\mathrm{X}$-axis and the frequency of identification with the census racial categories (in the case of Mexico, those of the I92 I census) on the Y-axis.

Figure 3 shows similarities and differences between Brazil and Mexico. Overall, it is important to mention that both countries have a similar average to skin color rating by interviewer (4.5 in Brazil and 4.I for Mexico), although the standard deviation in Brazil is higher than in Mexico (2 versus I.5). Those respondents who identified as pardos/mestizos also have a similar curve in Brazil and Mexico, and occupy an intermediate position between white and black in Brazil, and between white and indigenous in Mexico.

However, Figure 3 also shows a stronger overlap between ethnoracial identification and perceptions of skin color in Brazil when compared to Mexico. This is particularly strong for those who identified as black and white. In Brazil, the large majority $(73.2 \%)$ of persons with skin color rated as 3 or less identified as white (or $70.2 \%$ of those who identified as white versus $15 \%$ as pardo). Among those whose skin color was ranked 6 or higher, $45.1 \%$ identified as black (90.I\% of those who identified as black, versus $32 \%$ as pardos). 
Brazil

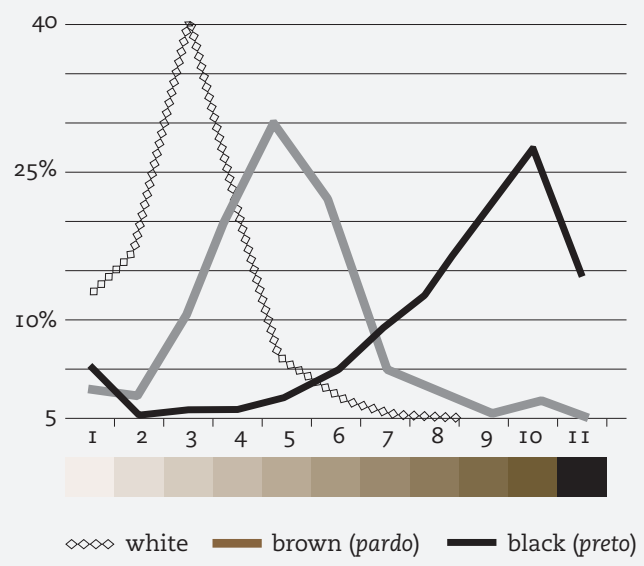

Mexico

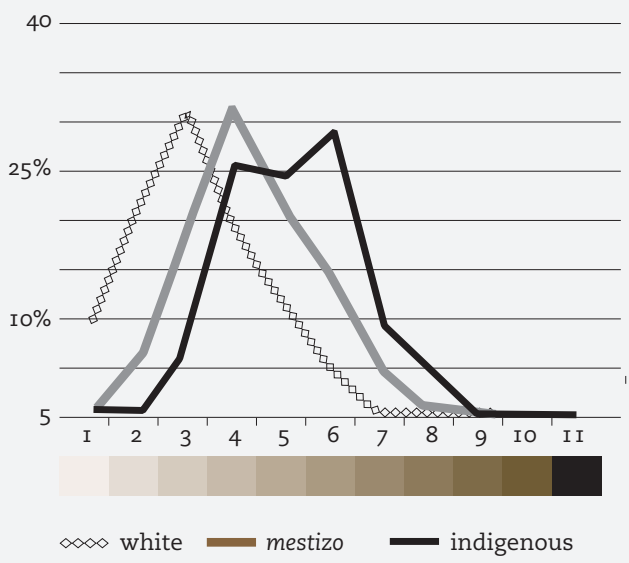

Figure 3

Racial ID and Skin Color in Brazil and Mexico

Source: PERLA, 2010

The distribution in Brazil contrasts particularly with the Mexican distribution in the case of whites. While there is a tendency in Mexico for those perceived as having lighter skin tones to identify as white, $58 \%$ of these people were categorized as having medium or dark skin tones (colors 4-I I in the I I-point color scale). On the other hand, $24 \%$ of those who identified as mestizos were rated as having light skin tone ( $\mathrm{I}-3)$. In other words, there is a considerable overlap in the color distribution of the three categories in Mexico, particularly if compared to Brazil.

These findings confirm the impact of the historical differences in how official ethnoracial categories were constructed in Brazil and Mexico. While in Brazil skin color has been the category used to measure mixing, in Mexico language assimilation became the category to assess the national project of mestizaje.

However, in both countries ideas of racial mixture were translated into the creation and persistence of a racially mixed category, which has been embraced by a large part of the population across the color spectrum. But while mestizo identification became the official national identity in Mexico, unrelated to color, in Brazil the term pardo is underplayed as a skin color description that seems to exclude the lighter and the darker (Moraes Silva \& Souza Leão, 20I2). Maybe the word most equivalent to mestizo would be the term moreno, which is commonly used as a polite descriptor of dark-skinned individuals (Sheriff, 200I). But even the moreno identification is less frequent than the white one in Brazil (e.g. survey Datafolha 2008). 
But how can we explain that the racially mixed category, pardo, has been mobilized to denounce racial inequality in Brazil, while in Mexico the category of mestizo remains key to reinforcing the boundaries between the indigenous and non-indigenous populations? We believe that the cultural meaning attributed to racial categories might further help us understand these differences.

\section{RACIAL MIXING AND CULTURAL DIFFERENCES}

As much of the literature acknowledges, the idea of mestizaje includes not only a biological element, illustrated by the idea of whitening, but also, and maybe more importantly, the idea that cultures should be mixed. As illustrated by Freyre's myth of the three races or Vasconcelos's cosmic race, the national culture of racially mixed peoples was described as the melting pot of European, African and indigenous cultures. However, once created, this national culture becomes a homogeneous unified culture. Cultural mestizaje (De la Cadena, 2000) relies on a constant reification of cultural differences, where difference is the driving force that guides the efforts of mixture, integration, assimilation and more recently recognition.

As summarized by Wade (I997), this idea is simultaneously inclusive, assuming that all nationals are equal, and exclusive, since difference is not allowed and should be assimilated. Those not participating in the mixture are usually perceived as a threat to the process of national unity. As discussed in the first section, this exclusionary feature has been historically expressed by the exclusion of the German language in Brazil and Chinese in Mexico. More recently those who oppose racially targeted policies, describe these as a source of dangerous divisions because they encourage esentialized understandings of race (Fry et al., 2007).

PERLA analyzed the role of difference by asking respondents in the two countries about their perceptions of difference from other ethnoracial groups in terms of their culture and habits, as well as the way they treat their kids and their sexual practices. In Brazil, those who identified as white were asked to respond about negros and indigenous people; those who identified as black were asked to respond about whites and indigenous people, and those who identified as pardo were asked to respond about whites, negros and indigenous people. In Mexico, those who identified as white were asked about indigenous people and those who identified as indigenous people were asked about whites. Those who identified as mestizo were asked about whites and indigenous people. Table I summarizes our findings:

Table I

Perception of Ethnoracial Differences in Brazil and Mexico

$\%$ of those who consider their ethnoracial group different

(or very different in relation to)

Source: PERLA, 2010 


\begin{tabular}{l|l|l|l|l|l|l}
\multirow{2}{*}{ Perception of difference in: } & \multicolumn{2}{|l|}{ Brazil } & \multicolumn{2}{l}{ Mexico } \\
\cline { 2 - 7 } & $\begin{array}{l}\text { Culture } \\
\text { and habits }\end{array}$ & $\begin{array}{l}\text { Way they } \\
\text { treat kids }\end{array}$ & $\begin{array}{l}\text { Sexual } \\
\text { practices }\end{array}$ & $\begin{array}{l}\text { Culture } \\
\text { and habits }\end{array}$ & $\begin{array}{l}\text { Way they } \\
\text { treat kids }\end{array}$ & $\begin{array}{l}\text { Sexual } \\
\text { practices }\end{array}$ \\
\hline $\begin{array}{l}\% \text { of Whites towards } \\
\text { Black (negros BR) / Indigenous(ME) }\end{array}$ & $24.9 \%$ & $16.9 \%$ & $9.9 \%$ & $79.9 \%$ & $6 \mathrm{I} .9 \%$ & $52.2 \%$ \\
\hline $\begin{array}{l}\% \text { of Browns (BR) / Mestizos (ME) } \\
\text { towards Black (negros BR) / } \\
\text { Indigenous(ME) }\end{array}$ & $16.5 \%$ & $\mathrm{II.I} \%$ & $7 \%$ & $58 \%$ & $46.8 \%$ & $4 \mathrm{I} .3 \%$ \\
\hline $\begin{array}{l}\% \text { of Black (negros BR) / Indigenous(ME } \\
\text { towards Whites }\end{array}$ & $20.3 \%$ & $16.6 \%$ & $\mathrm{I} 2.9 \%$ & $56 \%$ & $49.7 \%$ & $47 . \mathrm{\%} \%$ \\
\hline $\begin{array}{l}\% \text { of Browns (BR) / Mestizos (ME) } \\
\text { towards Whites }\end{array}$ & $\mathrm{I4.3 \%}$ & $14.9 \%$ & $9.1 \%$ & $39.5 \%$ & $35.4 \%$ & $32.4 \%$ \\
\hline $\begin{array}{l}\% \text { of three groups (only in Brazil) } \\
\text { towards Indigenous }\end{array}$ & $80 \%$ & $60 \%$ & $50 \%$ & $\mathrm{n} / \mathrm{i}$ & $\mathrm{n} / \mathrm{i}$ & $\mathrm{n} / \mathrm{i}$ \\
\hline
\end{tabular}

Table I shows that, overall, perceived cultural differences are considerably stronger in Mexico compared to Brazil. About half of respondents, across ethnoracial groups, perceived other groups as different (or very different) in their culture and habits, in the way they treat their kids, and in their sexual habits. In contrast, in Brazil, perceptions of differences are generally much lower, even though one-fourth of white people still perceive black people to be different in their culture and, likewise, one-fifth of black people perceive white people to be different in their culture and habits.

Nevertheless, the last row of the table shows that Brazilian perceptions of difference towards indigenous people is strikingly similar to that of Mexican whites, over $50 \%$ across all dimensions of difference. This finding seems to confirm Wade's analysis of the perception of the black population as a race and the indigenous population as a cultural/ethnic group beyond academic analysis. In other words, while black people are perceived as culturally similar in Brazil, indigenous people are perceived as cultural others. This is particularly striking if we take into consideration the important demographic and historical differences in the construction of indigenous identity in the two countries.

Finally, the perceptions of those who identified themselves as mestizo or pardo are worth mentioning. In Brazil, pardos tend to have the lowest perception of difference in relation to both the white and indigenous populations. Even though this difference is not statistically significant, it shows that pardos might see themselves as in-between these groups. In Mexico, mestizos also show slightly lower perceptions of difference towards indigenous groups than white people and lower perceptions of difference towards white people than indigenous people. Nevertheless, nearly half of all mestizos see themselves as being different or very different to the indigenous population across all dimensions. The perception of difference towards white people is weaker, but still one third of mestizos perceive themselves as being different or very different to white people across all dimensions (in contrast to one-sixth in Brazil). 
Overall, these findings suggest that perceptions of cultural differences between indigenous and non-indigenous populations continue to be a driving force of ethnoracial relations in Mexico. In Brazil, the continuing affirmation of color hierarchies has prevailed over black cultural difference - a process reinforced by the incorporation of 'black culture' as a key element of a single shared Brazilian culture.

But these findings leave us with a hanging question of "so-what?": what effect, if any, do these differences have on current patterns of ethnoracial inequalities in these two countries?

\section{RACIAL MIXING AND ETHNORACIAL INEQUALITIES}

As we have seen so far, each country's "technologies of mestizaje," to paraphrase Foucault, where built on different axes. Brazil's racial project was constructed around the desire for whitening and/or un-blackening through an ideology of racial mixture based on a skin color continuum. In Mexico the control of the indigenous population was foreseen through their cultural assimilation, thus the racial mixture was built around a 'preoccupation' with cultural differences (Hooker, 2005; Saldivar, 2014; Wade, I997).

These differences may lead to distinct impacts on ethnoracial inequalities. For example, the color continuum in Brazil has been presented as having a beneficial effect, by allowing racially-mixed individuals to be upwardly mobile. The idea that mixed-race individuals would be more successful and upwardly mobile was explicitly propounded in Brazilian academia at least until the early I970s as the 'mulatto escape hatch' thesis (Degler, I97I). In the I970s the PhD dissertations of Carlos Hasenbalg (I979) and Nelson do Vale e Silva (I979), both relying on census data and submitted in the United States, directly rejected the latter theory: both works showed that the socioeconomic position of pardos/brown people was much more similar to that of the black population than to the white. In fact, they found nearly no significant difference in socioeconomic status of blacks and browns in Brazil. Since then, a number of studies have confirmed that the socioeconomic status of brown and black populations was very similar in Brazil throughout the twentieth century, and much worse than that of white people (Telles, 2004). Nevertheless, a comparison with Mexico may indicate that the socioeconomic boundaries between white and non-white in Brazil are weaker than those between indigenous and non-indigenous, since the cultural difference argument may leave indigenous people further excluded and blame them for their own situation.

On the other hand, the lack of emphasis on skin color in Mexico may create a color-blind environment in which skin color is not relevant to socioeconomic outcomes, since ethnoracial identifications do not rely on them. Only the indigenous/non-indigenous boundary, therefore, would be relevant for explaining inequality. The premise behind the policy not to collect statistics on 
race and racial identification in Mexico seems to be that, beyond cultural differences measured by language, ethnoracial identity is irrelevant to social stratification (Aguirre Beltrán, I992). As a consequence, schooling and learning Spanish have been the most favored strategies to combat exclusion. The underlying assumption is that once you acquire the mestizo identity, your wellbeing will increase. If this assumption is correct, there should be no difference in SES between mestizo and white populations, for example.

PERLA allows us to compare how ethnoracial categories and socioeconomic outcomes are correlated in Brazil and Mexico. As mentioned, in Brazil a number of studies based on census and larger national household surveys have already confirmed the significant effect of ethnoracial categories, even after controlling by class. In the case of Mexico, the significance of ethnoracial categories for inequality is more contested, even if recently accepted in policy and academic circles.

In addition, by using the color palette, PERLA allow us to compare inequalities based on ethnoracial categories and perceptions about skin color, more directly addressing the existence of a color continuum in Brazil and/or a colorblindness in Mexico. To enable a more straightforward comparison, we divided the interviewer skin color rating based on the color palette into three groups: rated I-3 (light), rated 4-5 (medium), rated 6 or higher (dark).

We use average years of schooling as a proxy for socioeconomic attainment. Because income measures are not typically reliable, especially in smaller survey samples like ours, and because the occupational structure of these two countries is very different, years of schooling would seem to be a more straightforward source of comparison. Nevertheless, differences in national averages have to be taken into account.

Figure 4 summarizes our results, presenting the average years of schooling for those who identified as white, brown and black in Brazil and white, mestizo and indigenous in Mexico. In both countries we also compared the average years of schooling of those classified as light, medium and dark, according to the color palette.

Regarding inequalities based on ethnoracial identification, Figure 4 generally confirms previous findings on the Brazilian case. Those who identified as white have a substantial advantage (one more year of schooling, on average) compared to those who did not identify as white, either as pardo (brown) or preto (black). In the Mexican case, mestizos have a higher average of years of education compared to both those people who identified as white (+I.I years) and especially those who identified as indigenous (+2.2 years). In short, contrary to Brazil, those identified as mestizo have an advantage in terms of years of schooling. 
Brazil

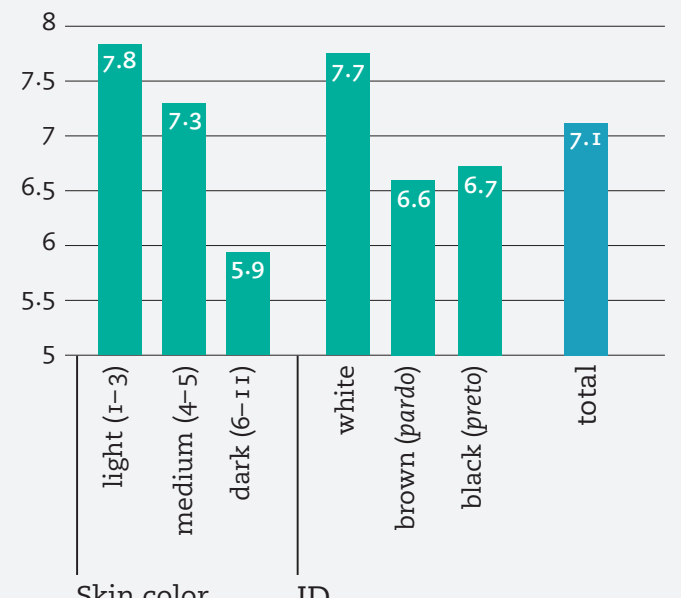

México

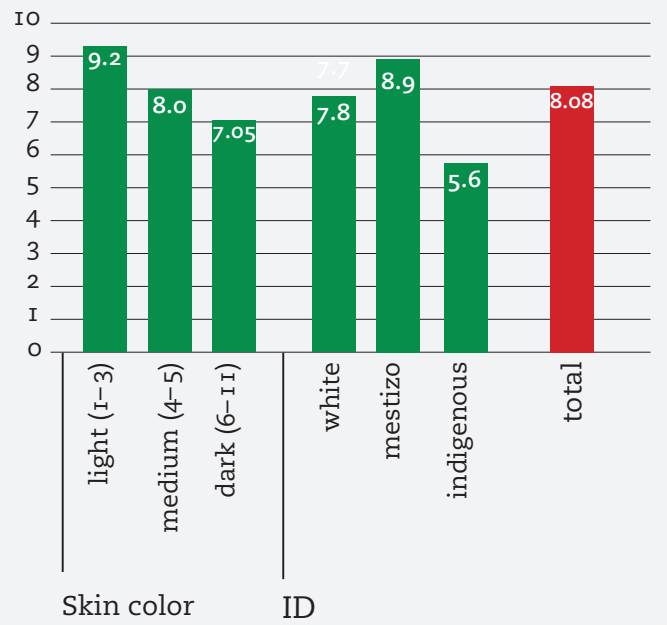

Figure 4

Average Years of Schooling by Ethnoracial and Skin-Color Groups

Source: PERLA, 2010

At first glance, this finding would seem to confirm the assumption that, in Mexico, a racially mixed identity is an advantage, since those who identified as white have, on average, one less year of education. These results indicate that while white advantage exists in Brazil, there is indigenous disadvantage in Mexico. However, the schooling gap between those who identified as indigenous and those who identified as mestizo in Mexico is much larger than the gap between those identifying as white in Brazil and those who do not. This partly confirms the additional burden of the reification of cultural difference in creating stronger socioeconomic inequalities.

When we turn to the comparison based on the color palette, the first striking find is the similar distribution in the two countries, with lightest skinned people having the highest average of schooling and darkest, the lowest. Despite the different scales used in the two graphs (due to the higher average years of schooling of Mexicans), the difference between lightest and darkest is similar in both countries: about two years.

In Brazil, it was possible to verify the partial existence of a color continuum. Those whose skin color was ranked medium had an average of 7.3 years of education, 0.7 less than those ranked light and I.4 more than those ranked 
dark. But only the differences between the light and dark groups were statistically significant. Moreover, the difference between medium and dark is stronger than between medium and light.

Interestingly, those ranked medium had an average schooling 0.7 years higher than those who self-identified as brown, indicating a significant disconnect between skin color and racial identification in Brazil. In contrast, those whose skin color was ranked as dark had an average of 5.8 years of education, 0.8 less than those who self-identified as black. This suggests that a number of higher achieving respondents, who were ranked as medium or light, opted to identify as black - which may indicate a growing racial awareness. The fact that inequalities appear to increase when we use classifications based on the interviewer's skin-color rating provides further evidence that skin color is an independent variable in this correlation, rather than a product of an endogeneity issue (i.e. better off black/brown people identifying as white).

While in Brazil the group classified as dark had the lowest average years of schooling, in Mexico the most disadvantaged group were those who identified as indigenous. This partly confirms the role of skin color in Brazil and the role of cultural exclusion in Mexico. Nevertheless, even though we could not find a strong correlation between skin color and identity in Mexico (Figure 3), skin color seems to influence educational attainment (Figure 4). As mentioned earlier, the gap between darker and lighter skin is statistically significant and similar to the Brazilian case.

Given that the correlation between skin color and self-ascription is not high in Mexico, but skin color does play a role in educational attainment, in the following figure we explore variations in average of years of schooling according to skin color classification, controlling for ethnoracial identification.

In Figure 5 we can see how skin color affects years of schooling within groups. While dark-skinned mestizo and indigenous people remain relatively the same compared to the national average of their groups (5.6 indigenous and 8.9 mestizo), dark-skinned white people have almost 2 years less schooling than the national average for their color ( 7.8 years). But where skin color matters most is for those with light skin: in all the groups, light-skinned people had between I.5 and 2 years more schooling. This indicates that although dark skin does not seem determinant, with the exception of white people, when it comes to years of schooling, light skin considerably increases the possibility of completing more years.

In short, at first glance, the broad definition of the mestizo racial identification seems to have been much more 'successful' at erasing socioeconomic boundaries in Mexico compared to the pardo/brown definition in Brazil. Nevertheless, if we take skin color classification as a proxy to measure non-cultural aspects of race (with the assumption that skin color is an important marker for discrimination), it is clear that racial socioeconomic disparities are still very strong in Mexico, beyond the cultural indigenous/non-indigenous boundary. 


\section{I5}

IO

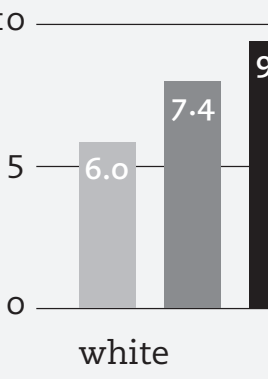

9.2
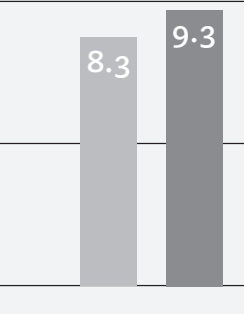

mestizo

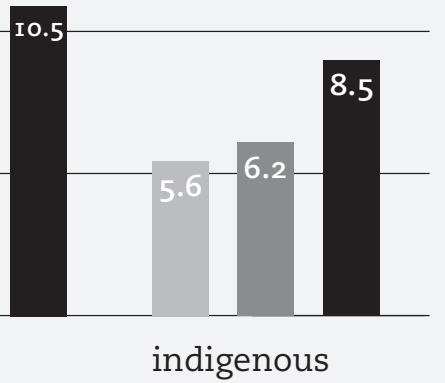

light medium dark

Figure 5

Average years of schooling by skin color categorization and ethnoracial classification in Mexico.

Source: PERLA, 2010

\section{DISCUSSION AND CONCLUDING REMARKS}

It is almost universally accepted today that Brazil and Mexico, like most Latin American countries, have tended to underplay the role of racism in their his torical formation through discourses of racial mixture. Although we generally agree with this statement, in this paper we have argued that it is important to move beyond it, exploring the different ways in which these countries have mobilized racial mixtures discourses in their racial formation projects. A comparative approach to the region is crucial to move away from normative descriptions and better understand the persistence of racial hierarchies in contexts of widespread racial mixture.

In both countries we found the persistent centrality of racial differences in socioeconomic outcomes, albeit through different national boundaries: white versus non-white in Brazil and indigenous versus non-indigenous in Mexico. Skin color was also significantly related to inequality in both contexts - characterizing what Telles and the PERLA team (2014) has called the Latin American pigmentocracies. But we also found striking differences in the correlation between skin color rating and racial identification, much stronger in Brazil than in Mexico. The latter finding is related to the salience of cultural differences in 
Mexico, which seem to play a role in the exclusion of indigenous people. Nevertheless, when looking at skin color differences within each identity group in Mexico, it is clear that skin color plays an important role in stratification.

These differences may help explain the different consequences of racial mixture in Brazil and Mexico today. While in Brazil affirmative action policies for brown and black populations have been implemented and some authors have identified trends of racial 'unmixing' (Bailey, 2009), in Mexico policies have continuously relied on a focus on indigenous culture, bringing together mestizo and white, and making the racial hierarchy less visible (Moreno Figueroa, 20 Io). Since the gradual return to democracy in the I980s, Brazilian black movements have denounced the myth of racial democracy by evidencing the persistence of racism in the country. Since the I 990 s they have found a growing echo in the State. Backed by statistical data and international agreements, affirmative action policies have been implemented for black people (preto and pardo) in public universities, which have become mandatory in all federal universities (the most selective in the country) since 2013. Quotas for black and brown candidates to federal public offices have also recently been approved. Simultaneously, Brazil has increasingly collected data on racial identification in different realms in order to measure racial inequality. In 20I0, for the first time since I940, Brazil was a country with a majority non-white population - a clear rejection of the 'whitening' aspiration that historically seemed to guide identification in the country.

Nevertheless, racial mixture has important consequences for the implementation of these policies. The tendency in affirmative action policies is to combine black and poor white populations as similarly excluded (Feres Júnior et al., 20I3). Recognition is not seen as an important aspect of fighting racial inequality. Instead, people commonly claim that if poor sectors are targeted, racial inequality will also be solved (an idea implicit even in affirmative action policies, which increasingly focus on poor and black populations). Even though most people recognize racial inequality and even discrimination, they have a harder time seeing any difference in being black. In addition, while racial inequality places black and brown populations together at the lower end of the socioeconomic hierarchy, racism and discrimination are only seen to impact those who are black. Racism is recognized as a historical residue or an attitude shared by a few ignorant people, not as a structural mechanism of present-day discrimination (Moraes Silva, 20I2). This is why cultural assimilation is the non-spoken assumption and there is little space to discuss white privilege.

In Mexico, recent indigenous mobilizations and increasing international pressure have also had consequences in terms of a growing acknowledgement of ethnoracial inequalities. But if, as in Brazil, the mestizaje project has been contested, its focus on cultural differences has remained largely untouched. The consequence has been the creation of recognition policies but little redis- 
tribution. Nothing similar to Brazilian affirmative action is currently debated. Finally, similarly to Brazil, the focus on indigenous rights has failed to address a central aspect of racial inequalities: the existence of racial hierarchies and privilege (Saldivar, 20I4).

How have different Latin American mestizaje projects been translated into modern multicultural discourses? Does a cultural emphasis make it easier to organize around collective rights (as argued by Hooker) or does it equate mestizaje with assimilation? Can the emphasis on color allow for a more inclusive definition of blackness as a collective identity, or does it outlaw the creation of identity boundaries between black and white populations? These are important questions that can only be answered through a closer look within the region and its varieties of racial mixture formations.

Received on 6/IO/20I7 | Revised on II/I/20I8| Approved on 3I/I/20I8

Graziella Moraes Silva is assistant professor of Sociology at the Graduate Institute of International and Development Studies (IHEID), Geneva, and at the Federal University of Rio de Janeiro (UFRJ), associated to the Program in Sociology and Anthropology (PPGSA) and to the Interdisciplinary Nucleus of Studies on Inequality (NIED). She is one of the authors of Getting respect: dealing with stigmatization and discrimination in the United States, Brazil and Israel (20I6), and Pigmentocracies: ethnicity, race, and color in Latin America (2014). Her current research projects focus on comparative race relations and elite's perceptions of poverty and inequality.

Emiko Saldivar is Associate Researcher and Lecturer at the University of California, Santa Barbara (UCSB). She is founding member of Mexico's antiracist collective COPERA (Colectivo para Eliminar el Racismo) and Coordinator of the Hemispheric Activist Research Anti-Racist Network RAIAR (Red de Acción-Investigación Anti-Racista). She is one of the authors of Pigmentocracies: ethnicity, race, and color in Latin America (20I4), and has published several articles and books chapters both in Spanish and English on mestizaje, racial statistics, interculturality an anti-black racism in Mexico. 


\section{NOTES}

I In this paper we use racial mixing and mestizaje as synonyms. Our focus is on the ideological centrality of racial mixing in Latin America, where it also created strong hybrid identification as mestizos, morenos, mulattos and pardos.

2 We use the term ethnoracial to refer to distinctions based on biological notions of race or skin color and/or on cultural practices and regional belonging.

3 Because indigenous people were only a small fraction of the Brazilian population, their mention was more symbolic than based on actual social policies. Nevertheless, Vargas envisioned a march to the west that would help integrate the few remaining nomadic indigenous groups. For more information, see Garfield, 2001.

4 With the exception of the I9I0, I920, I930 and I970 Censuses.

5 The idea of changing the question was justified by the perception that previous categories had referred to color, while indigenous identity refers to race.

6 The reason why the frequency of pardos was so low in 1940 was that pardo or mestizo was not included at that time as an option for interviewers, who could only use the category residual/other.

7 Their understanding is that the mixed-race category masks Brazilian racial inequalities, encouraging black people to 'whiten' themselves through the pardo identification. Indeed, a large number of statistical studies (enabled by the availability of racial data) have shown that the socioeconomic status of brown and black populations is very similar in Brazil, and much worse than for the white population.

8 Furthermore, the relationship between the Mexican state and indigenous people was deeply transformed by the indigenous uprising in I994, which prompted legal reforms and a reconsideration of the relationship between the state and indigenous people (Hernández, Paz \& Sierra, 2004; Saldivar, 2008).

9 “Is (interviewee's name) Náhuatl, Maya, Zapoteco, Mixteco or that of another indigenous group?" 
Io "De acuerdo con la cultura de (NOMBRE), ¿ella (él) se considera indígena?" Once again, this question was only present in the expanded version of the survey.

I I The survey was also conducted in Peru and Colombia. For more information, see: Telles \& PERLA, 2014.

I2 Although this sample included a few respondents who identified as black in Mexico and as indigenous or Asian in Brazil, they were excluded from our analysis due to their small numbers.

I3 In 20I0, in a partnership with PERLA coordinator Edward Telles, LAPOP included a few questions on racial identification similar to the questions contained in PERLA.

I4 The remaining respondents were $3 \%$ yellow/Asian, I.9\% indigenous and $2.5 \%$ other. $0.7 \%$ did not know or did not wish to answer.

I5 In addition, $3 \%$ of respondents identified as black or AfroMexican, $3.5 \%$ as other and $4 \%$ refused to reply.

I6 For the complete study report, see: http://www.ibge.gov. br/home/estatistica/populacao/caracteristicas_raciais/ default_raciais.shtm

\section{BIBLIOGRAPHY}

Aguirre Beltrán, Gonzalo. (1992) [1969]. Oposición de raza y cultura en el pensamiento antropológico mexicano. In: Obra polémica. México: Ediciones Fuente Cultural.

Appelbaum, Nancy P., Macpherson, Anne S. \& Rosemblatt, Karin Alejandra. (2003). Introduction: racial nations. In: Appelbaum, Nancy P., Macpherson, Anne S. \& Rosemblatt, Karin Alejandra (eds.). Race and nation in modern Latin America. Chapell Hill: The University of North Carolina Press, p. I-3I.

Bailey, Stanley. (2009). Legacies of race: identities, attitudes and politics in Brazil. Palo Alto: Stanford University Press. Banton, Michael. (I998). Racial theories. Cambridge: Cambridge University Press.

Bonilla-Silva, Eduardo. (2004). Race in the World System. Du Bois Review, I/I, p. I89-I94. 
CONAPRED. (20I0). Encuesta Nacional sobre Discriminación. Available at <http://www.conapred.org.mx/userfiles/files/ Enadis-20IO-RG-Accss-ooI.pdf.> Access on 20/4/2018.

Cunha, Olívia. (I999). Sua alma em sua palma: identificando a "raça" e inventando a nação. In: Pandolfi, Dulce (ed.). Repensando o Estado Novo. Rio de Janeiro: Editora FGV. Cunin, Elizabeth. (2002). Chicago bajo el trópico o las virtudes heurísticas del mestizaje. Revista Colombiana de Antropología, 38, p. II-44.

Degler, Carl N. (I97I). Neither black nor white: slavery and race relations in Brazil and the United States. New York: Macmillan.

De la Cadena, Marisol. (2000). Indigenous mestizos: the politics of race and culture in Cuzco, Peru, I9I9-I99I. Durham: Duke University Press.

Feres Júnior, João et al. (2013). O impacto da Lei no I 2.7 I I sobre as universidades federais. Levantamento das politcas de ação afirmativas (GEMAA). Rio de Janeiro: Iesp-Uerj.

Freyre, Gilberto. (I946) [I933]. The masters and the slaves: a study in the development of Brazilian civilization. Translated by Samuel Putnam. New York: Alfred Knopf.

Fry, Peter et al. (2007). Divisões perigosas: políticas raciais no Brasil contemporâneo. Rio de Janeiro: Civilização Brasileira.

Gamio, Manuel. (2010) [I9I6]. Forjando patria. Boulder: University of Colorado Press.

Garfield, Seth. (200I). Indigenous struggle at the heart of Brazil: state policy, frontier expansion, and the Xavante Indians, I937-I988. Durham: Duke University Press.

Hanchard, Michael George. (1994). Orpheus and power: the Movimento Negro of Rio de Janeiro and São Paulo, Brazil, I945I988. Princeton: Princeton University Press.

Harris, Marvin. (1964). Patterns of race in the Americas. Westport: Greenwood Press.

Hasenbalg, Carlos Alfredo. (I979). Discriminação e desigualdades raciais no Brasil. Rio de Janeiro: Graal.

Hernández, Rosalva Aida; Paz, Sarela \& Sierra, María Teresa. (2004). El Estado y los Indígenas en tiempos del PAN: neoindigenismo, legalidad e identidad. México: CIESAS/Porrúa. 
Hooker, Juliet. (2005). Indigenous inclusion/black exclusion: race, ethnicity and multicultural citizenship in Latin America. Journal of Latin American Studies, 37/2, p. 853IO.

INEGI. (2013). Perfil sociodemográfico: Estados Unidos Mexicanos. Censo de población y vivienda. Available at <http:// internet.contenidos.inegi.org.mx/contenidos/Productos/ prod_serv/contenidos/espanol/bvinegi/productos/censos/ poblacion/20Io/perfil_socio/uem/7028250476IO_I.pdf >. Access on $20 / 4 / 2018$.

INEGI. (20Io). Censo de Población y Vivienda. Available at <http://www.beta.inegi.org.mx/proyectos/ccpv/20Io/>. Access on 5/5/2018.

INEGI. (I996). Estados Unidos Mexicanos. Cien Años de Censos de Población.

Knight, Alan. (I990). Racism, revolution, and indigenismo: México, I910-I940. In: Graham, Richard (ed.). The idea of race in Latin America, I870-I940. Austin: University of Texas Press, p. 7I-II3.

LAPOP. (20I0). Available at <https://www.vanderbilt.edu/ lapop/ab2oio.php>. Access on 5/5/2018.

Lomnitz-Adler, Claudio. (I996). Las salidas del labarinto. México: Joaquín Mortiz.

Maio, Marcos Chor. (I999). O Projeto Unesco e a agenda das relações raciais no Brasil nos anos 40 e 50 . Revista Brasileira de Ciências Sociais, I4/4I, p. I4I-I58.

Martínez Casas, Regina. (2009). Vivir invisibles. La resignificacion cultural entre los otomies urbanos de Guadalajara. México: CIESAS.

Martínez Casas, Regina et al. (20I4). The different faces of mestizaje: ethnicity and race in Mexico. In: Telles, Edward \& PERLA (eds.). Pigmentocracies: ethnicity, race, and color in Latin America. Chapel Hill: University of North Carolina Press.

Martinez Novo, Carmen. (2006). Who defines indigenous people? New Brunswick: Rutgers University Press.

Marx, Anthony. (1998). Making race and nation: a comparison of South Africa, the United States and Brazil. Cambridge: Cambridge University Press. 
Moraes Silva, Graziella. (2012). Folk conceptualizations of racism and antiracism in Brazil and South Africa. Ethnic and Racial Studies, 35/3, p. 506-522.

Moraes Silva, Graziella \& Souza Leão, Luciana. (2012). O paradoxo da mistura: identidades, desigualdades e percepção de discriminação entre brasileiros pardos. Revista Brasileira de Ciências Sociais, 27/80, p. II7-I33.

Moreno Figueroa, Monica. (2010). Distributed intensities: whiteness, mestizaje and the logics of Mexican racism. Ethnicities, Io/3, p. 387-401.

Moreno Figueroa, Monica \& Saldivar, Emiko. (2015). "We are not racists, we are Mexicans": privilege, nationalism and post-race ideology in Mexico. Critical Sociology, 42/4-5. Nobles, Melissa. (2000). Shades of citizenship: race and the census in modern politics. Stanford: Stanford University Press. Poole, Deborah. (2004). An image of "our Indian": type photographs and racial sentiments. Hispanic American Historical Review, 84/I, p. 37-82.

Powell, Brenna Marea \& Moraes Silva, Graziella. (2018). Technocrats' compromises: defining race and the struggle for equality in Brazil, I970-2010. Journal of Latin American Studies, 50/I, p. 87-II5.

Renique, Gerardo. (2003). Anti-Chinese racism, nationalism and state formation in post-revolutionary Mexico, I920s-I930s. In: Appelbaum, Nancy P., Macpherson, Anne S. \& Rosemblatt, Karin Alejandra (eds.). Race and nation in modern Latin America. Chapel Hill: University of North Carolina Press, p. 2 I I-236.

Saldivar, Emiko. (20I4). 'It's not race, it's culture': untangling racial politics in Mexico. Latin American and Caribbean Ethnic Studies, 9/I, p. 89-I08.

Saldivar, Emiko. (2008). Prácticas cotidianas del estado: una etnografía del indigenismo. México: Universidad Iberoamericana.

Saldivar, Emiko \& Walsh, Casey. (20I4). Race, ethnicity and social identities in Mexican statistics. Journal of Iberian and Latin American Research, 20/3, p. 455-475.

Seyferth, Giralda. (I997). A assimilação dos imigrantes como questão nacional. Mana, 3/I, p. 95-I3I. 
Sheriff, Robin E. (200I). Dreaming equality: color, race, and racism in urban Brazil. New Brunswick: Rutgers University Press. Skidmore, Thomas. (1976). Preto no branco: raça e nacionalidade no pensamento brasileiro. São Paulo: Paz e Terra.

Stepan, Nancy. (I99I). The hour of eugenics: race, gender, and nation in Latin America. Ithaca: Cornell University Press.

Stern, Alexandra Minna. (2009). Eugenics and racial classification in modern Mexican America. In: Deans-Smith, Susan \& Katzew, Ilona (eds.). Race and classification: the case of Mexican America. Palo Alto: Stanford University Press, p. I5I-I73.

Sue, Christina A. (2013). Land of the cosmic race: racism, race mixture, and blackness in Mexico. New York: Oxford.

Telles, Edward Eric. (2004). Race in another America: the significance of skin color in Brazil. Princeton: Princeton University Press.

Telles, Edward Eric. (2003). Racismo à brasileira: uma nova perspectiva sociológica. Rio de Janeiro: Relume-Dumará/ Fundação Ford.

Telles, Edward \& Garcia, Denia. (2013). Mestizaje and public opinion. Latin American Research Review, 48/3, p. I30-I52. Telles, Edward \& PERLA (Project on Ethnicity and Race in Latin America). (20I4). Pigmentocracies: ethnicity, race, and color in Latin America. Chapel Hill: University of North Carolina Press.

Vale e Silva, Nelson do. (I979). White-non-white income differentials: Brazil. PhD Thesis. University of Michigan.

Van den Bergue, Pierre. (1967). Race and racism: a comparative perspective. New York: Wiley.

Vasconcelos, José. (I966) [I925]. La Raza Cosmica. México: Espasa

Velazquez, Maria Elisa. (20II). Africanos y afrodescendientes en México: premisas que obstaculizan entender su pasado y presente. Cuicuilco, 5I, p. II-22.

Villareal, Andres. (2010). Stratification by skin color in contemporary Mexico. In: American Sociological Review, 75/5, p. 652-678.

Wade, Peter. (1997). Race and ethnicity in Latin America. London: Pluto Press. 


\section{COMPARANDO IDEOLOGIAS DE MISTURA RACIAL NA AMÉRICA LATINA: OS CASOS MEXICANO E BRASILEIRO}

Resumo

A partir do fortalecimento de discursos multiculturais e políticas identitárias no final do século XX, pesquisas em ciências sociais passaram cada vez mais a tratar as ideologias da mistura racial latino-americana como mitos que escondem (e, portanto, apoiam) a reprodução das desigualdades raciais. Esses estudos foram guiados principalmente por comparações entre países com mistura racial generalizada (geralmente Brasil, México ou Colômbia) e países em que a mistura foi censurada e menos visível (mais comumente, os EUA). Neste artigo, a mirada se orienta para as diversas maneiras pelas quais a mistura racial atualmente afeta as formações raciais na América Latina, olhando inicialmente para o Brasil e o México, dois dos maiores países da região, e também com a maior população afro-descendente e indígena do continente. Para tal comparação, analisamos os resultados do projeto PERLA.

\section{COMPARING IDEOLOGIES OF RACIAL MIXING IN LATIN AMERICA: BRAZIL AND MEXICO}

Abstract

By the end of the twentieth century, with the rise of multicultural discourses and identity politics, Latin American ideologies of racial mixture had become increasingly denounced as myths that conceal (and thus support) the reproduction of racial inequalities. These studies have largely been guided by comparisons between countries with widespread racial mixing (usually Brazil, Mexico or Colombia) and countries in which it was less encouraged and visible (most commonly, the USA). In this paper we move the focus to the diverse ways in which racial mixture currently impacts racial formations in the Latin America, looking initially at Brazil and Mexico, two of the largest countries in the region, and also those with the largest Afro-descendent and indigenous populations in the continent. For comparison, we analyze survey data from the PERLA project.
Palavras-chave

Raça;

cor;

mistura racial;

etnia;

Brasil e México.

\section{Keywords}

Race;

color;

racial mixture (mestizaje);

ethnicity;

Brazil and Mexico. 